\title{
Humor judaico e resiliência ${ }^{1}$
}

\author{
Nancy Rozenchan* \\ Universidade de São Paulo (USP) | São Paulo, Brasil \\ nrozench@usp.br
}

Em meio à pandemia e mantendo o distanciamento necessário, o que há de melhor do que ser agraciado com um espetáculo internacional on-line sobre Sholem Aleichem? Foi o que aconteceu no domingo passado. Como, ao se falar de humor judaico, o famoso autor ídiche não pode ser dispensado, é dele que nos servimos brevemente. No espetáculo, o ator Mike Burshtein nos brindou com uma linda leitura do conto infantil "Mir iz gut, ich bin a yussim" Traduzindo: Estou numa boa, sou órfão. Que morbidez! Será humor negro? Ser órfão e estar numa boa? É bem nisso que consiste um dos muitos aspectos do humor judaico. Rir da própria desventura. Antes que alguém venha a lamentar e a sentir pena do pobre menino, é dele mesmo que sai o antídoto contra demonstrações lamuriosas. Sua manifestação desmonta indesejados atos protetores que possam tolher sua recente liberdade de aproveitar e fazer o que lhe aprouver.

Antigamente, esse conto era ensinado em ídiche ou em hebraico na escola e, sem se dar conta, alunos aprendiam a lidar com uma situação trágica divertindo-se e muito. O humor judaico se aprende desde a infância. E a resiliência se beneficia dele.

O humor judaico reflete as experiências do povo judeu, frequentemente, com histórias que são autodepreciativas, um riso de si próprio e o dilema em que alguém se encontra como judeu. Muito desse humor ocorreu como um meio de tratar da perseguição e supressão encontrados em um mundo antijudaico. Ao rir da situação, o judeu ficava mais capacitado a sobreviver às dificuldades. Esse humor foi um modo de dizer ao opressor que havia pouco que pudesse ser feito ao judeu que ainda não houvesse acontecido e ao qual ele havia sobrevivido.

Sigmund Freud, em sua obra, sugeriu que muitas piadas judaicas apontam para a capacidade do povo judeu de (1) se envolver em uma autocrítica completa de si mesmo; (2) defender um modo de vida democrático; (3) enfatizar os princípios morais e sociais da religião judaica' (4) criticar o excesso de requisitos dela; e (5) refletir sobre a miséria de muitas comunidades judaicas. Freud, desse modo, presta uma homenagem à capacidade do povo judeu de superar as condições sociais opressivas que lhe foram impostas e sua capacidade de transcendê-las rindo delas.

\footnotetext{
${ }^{1}$ Texto inspirado em ABRAMI, Rabbi Leo M. It is not a joke. Mainstream, v. 48, n. 5, July-August 2002 e AUSUBEL, Nathan. A Treasury of Jewish Humor. Nova York: Doubleday, 1951.

* Professora Sênior de Língua e Literatura Hebraica da Universidade de São Paulo. 
Alguns psiquiatras não judeus parecem ter tido alguma dificuldade em entender a essência da sagacidade judaica e foram particularmente críticos em relação ao seu humor. Um deles, o Dr. Edmund Bergier, expressou a opinião de que há uma tendência definitiva ao "masoquismo psíquico" na sagacidade cômica judaica e que certas situações externas (discriminação, pobreza, a falta de oportunidade e a amargura da vida na Europa Oriental) predispuseram os judeus a certo grau de masoquismo.

Essas noções foram corrigidas, no entanto, por Theodor Reik, que observou que o aspecto masoquista da piada judaica pode ser não autêntico. É apenas pseudomasoquista porque o masoquismo da perspicácia cômica judaica é somente uma "máscara" que não mostra o rosto por trás disso. Pois o objetivo final dessa exibição é o desejo inconsciente de obter a aprovação - ou mesmo a admiração - do público e recuperar a dignidade de alguém.

Martin Grotjahn, outro psicanalista, resume o que significa promover uma agressão contra si mesmo: "Você não precisa nos atacar. Podemos fazer isso sozinhos e ainda melhor. Nós podemos aguentar. Conhecemos nossas fraquezas e, de certa forma, temos orgulho delas." Piadas judaicas, ele escreveu, contêm um tipo de resignação e, ocasionalmente, um orgulho obstinado. Eles parecem dizer: “É assim que somos e será enquanto existirmos".

Sabemos que existe muita resiliência e coragem em muitas das histórias do nosso povo e que isso serviu como uma espécie de mecanismo de defesa que nos permite enfrentar a adversidade. $O$ fato de os judeus serem capazes de tirar sarro impiedoso das deficiências de seu próprio povo é uma característica positiva, e não negativa. A autocrítica e até o autossarcasmo fazem parte do processo de pensamento do indivíduo comprometido com a integridade intelectual e moral.

O mundo mudou consideravelmente desde os anos em que tais conceitos foram emitidos. Podemos dizer, hoje, que o caráter universal da sagacidade humorística judaica passou a ser apreciado por muitos - judeus e não judeus. Alguns dos melhores humoristas da cena norte-americana são judeus, e muitas pessoas que não pertencem à comunidade aprenderam a curtir e a apreciar uma boa piada judaica.

Muitas piadas e anedotas acarretaram um impacto definitivo na mente e no caráter do povo judeu, porque são inspiradas por uma profunda sabedoria. Reik observou que ao usar o humor, o lamento geralmente se transforma em risos. Nathan Ausubel acha que o que faz os judeus rirem tanto da adversidade é o instinto de autopreservação.

"Rindo do nosso destino, é como se estivéssemos saindo de uma situação e olhando à distância, como se fôssemos observadores de fora, por assim dizer". O humor judaico é único, não apenas porque zomba de nossos defeitos e fraquezas, mas porque reflete sobre a história de nosso povo. 


\section{Arquivo Maaravi}

Revista Digital de Estudos Judaicos da UFMG

ISSN: 1982-3053

Manter-se vivo, apesar de todas as formas de opressão, tem sido uma das nossas principais preocupações ao longo dos séculos. Mesmo diante da destruição iminente, ainda pode haver alguma esperança. Desejamos que o mundo saiba que estamos determinados a sobreviver até ao pior inferno.

Como o nosso povo sobreviveu por milênios? É uma pergunta antiga. Uma resposta possível é que a capacidade de resiliência foi entremeada na tessitura do judaísmo ao longo de milhares de anos. $\mathrm{O}$ foco do judaísmo, tanto o espiritual quanto o prático, auxiliou as pessoas a viverem diante dos desafios, da dor e da tragédia; ajudou o povo a sobreviver. Mais exatamente, essa orientação para a resiliência pode nos servir muito bem hoje no atual ambiente político - se pudermos tirar algum proveito disso.

A resiliência pode ser definida como o processo de se adaptar bem diante de adversidades, traumas, tragédias, ameaças e até fontes significativas de estresse. $\mathrm{O}$ judaísmo, em geral, estimula a resiliência. Após cada catástrofe, o paradigma predominante deixava de funcionar: não sabíamos mais como nos entender em relação a Deus, a outros judeus e a outros povos. Todavia, ao longo da história, os judeus transcenderam catástrofes após catástrofes. Repetidamente insuflaram uma nova vida no povo e na civilização e encontraram caminhos para uma restauração. Tivemos que nos curar do trauma. Tivemos que nos recuperar e revisualizar, regenerar e ressemear uma vida judaica intensa. Encontramos maneiras de cultivar essas estratégias, individual e coletivamente.

Exploramos como o humor é um componente essencial da resiliência e o que isso significa para os judeus. O humor é mais do que apenas fazer rir - é esperança. É inestimável. É a sensação de que tudo ficará bem, mesmo que apenas por alguns momentos. É um lembrete de que você não está sozinho; um empurrão ajuda a continuar.

No judaísmo, há um certo orgulho quando se trata de rir e brincar, apesar do peso que nos rodeia. Não é iluminar uma situação, mas abordá-la de frente. É uma maneira de dizer: estou reconhecendo a realidade, mas estou comprometido em encontrar um caminho a seguir. Não é realista, nem otimista. É simplesmente a única maneira que sabemos. "Humor judaico" é esse coquetel estranho de franqueza, empatia, escuridão e resiliência.

Com o passar do tempo, corremos o risco de perder nossa capacidade de rir, e será necessário um esforço para impedir que isso aconteça. $\mathrm{O}$ mundo judaico deve continuar abrindo espaço para o riso, mesmo na escuridão. Pessoas resilientes usam algumas vezes humor para reduzir o estresse e para lidar com a dor, agonia e desespero inimagináveis. Fortaleçamos, rindo, de preferência, a nossa resiliência individual e coletiva aprimorando os nossos conhecimentos; as lives, encontros e debates virtuais estão aí disponíveis para todos. E para completar judaicamente: são de graça. 
Recebido em: 13/09/2020.

Aprovado em: 23/09/2020. 